\title{
Protein engineers to gain from telecommunications selloff
}

\section{Tokyo}

UNEXPECTEDLY, the privatization of Nippon Telegraph and Telephone (NTT) appears to have benefited Japan's molecular biologists. A small part of the massive funds flowing into the Japanese government coffers from the privatization will be channelled into the creation of a protein engineering research institute.

Last week NTT emerged on the Tokyo stock exchange as the largest private company in the world. Although sceptics considered the stock overvalued at $¥ 1.2 \mathrm{mil}$ lion $(\$ 8,000)$ per share, trading in NTT shares was paralysed for two days as buyers outnumbered sellers by a hundred to one. Only when the government released a further 100,000 shares on the market did trading get under way at $¥ 1.6$ million, and by the weekend the price had risen to nearly $¥ 1.8$ million. If the price holds, the government stands to make over $¥ 13$ million million from the sale of 50 per cent of NTT during the next three fiscal years.

While most of the money accruing from the privatization is expected to be swallowed by the government's huge fiscal deficit (debt servicing payments currently run at about $¥ 11$ million million a year), a small portion is being directed into support for the Japan Key Technology Center, an organization for the promotion of basic research that was established jointly by the Ministry of International Trade and

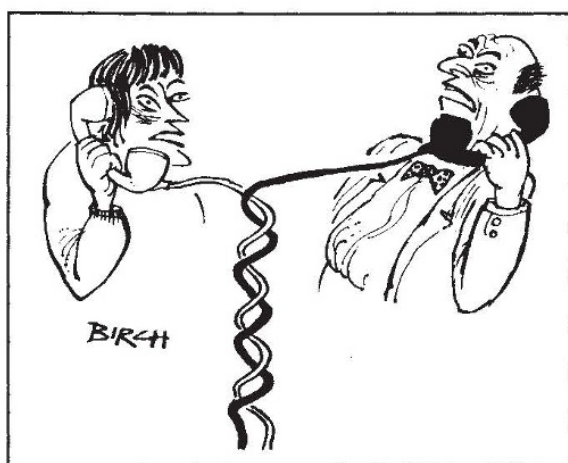

Industry (MITI) and the Ministry of Post and Telecommunications (MPT) in October 1985 (Nature 317, 99; 1985).

Ever since Japan Key Tech came into existence, the two ministries have been vying for the most prestigious project to be funded by it. This month MPT will establish an institute for the development of next-generation space communications, such as large-diameter antennas and miniaturized transmitters for space stations, with funding of $¥ 6,000$ million over eight years. But this pales in comparison with MITI's plans to build a protein engineering research institute.

About two years ago MITI counselled a group of advisors about suitable projects to establish in the field of molecular biology and biotechnology. The protein engineering institute was selected from a list of about twenty ideas drawn up by the group. Established as a joint-stock corporation in April last year, the institute will receive funds of around $¥ 17,000$ million over the next ten years. Fourteen biotechnology companies, including the 'big five' (Kyowa Hakko Kogyo Co., Takeda Chemical Industries Ltd, Toray Industries Inc., Mitsubishi Chemical Industries and Ajinomoto Co.), will contribute 30 per cent of the funds, the rest coming from Japan Key Tech.

The institute, which has temporarily set up headquarters in Tokyo, will move next spring to the former site of EXPO 70 in Suita City near Osaka, an area already endowed with several biotechnologyrelated institutes. The land for a threestorey laboratory is being provided rent free by the local Osaka government, which plans to build a bioscience institute next door, and it is expected that the Osaka government will take over the protein engineering institute when funding runs out in ten years.

Professor Morio Ikehara, managing director of the institute, plans to install the latest high-tech equipment, including a supercomputer and the world's most powerful nuclear magnetic resonance spectrometer $(600 \mathrm{MHz})$. There will be five departments - structural analysis of proteins, correlation between structure and function, production (genetic engineering), purification plus evaluation of functions, and a database and computer service department. But projects will be drawn from every department to encourage interdisciplinary research.

But at present a battle is raging between those on the management side of industry and the academics over organization and staffing of the institute. The academics are seeking talent with ideas, whereas those in industry want good management and a quick return on investment.

David Swinbanks
Washington
THE effort to map and ultimately to sequence the human genome has captured the attention of the White House. The cabinet level Domestic Policy Council (DPC) has asked its working group on biotechnology to prepare a report on the human genome project. A first instalment of the report, due next month, will detail present US activities. Future instalments could include a framework for coordinating federal activities on the project.

The working group will meet on $23 \mathrm{Feb}$ ruary to decide how best to proceed. According to David Kingsbury, its chairman, the report will probably be written by a subgroup on which the National Institutes of Health (NIH), the departments of Energy and State and the White House Office of Science and Technology Policy are expected to be represented.

The first report will be primarily to educate DPC members on the costs and benefits of pursuing the genome project. The notion that such an endeavour could cost $\$ 3,000$ million attracted White House attention. No federal agency is contemplating such a large project, but several are already working on parts of a sequencing and mapping project.

The plans of the Department of Energy (DoE) for the human genome project are the best defined. It is supporting the development of a set of DNA libraries specific to individual chromosomes. Work is under way at Los Alamos National Labor- atory on chromosome 16 and at Lawrence Livermore National Laboratory on chromosome 19. A consortium headed by Cassandra Smith at Columbia University is working on chromosomes 21 and X.

Charles DeLisi, who heads DoE's efforts, says that the department will spend approximately $\$ 5$ million on the human genome project in this fiscal year and $\$ 11.5$ million next year. As well as the DNA libraries, DoE will focus on new sequencing technology and computational activities. DeLisi says that techniques for calculating structure from sequences will become increasingly important. An advisory group met earlier this month to specify plans for this year's DoE activities.

NIH, which supports several projects that will be relevant to any mapping and sequencing effort, has not yet decided exactly what its role in the human genome project will be. NIH director James Wyngaarden chairs a small working group that will guide NIH directions on the project. George Palade of Yale University serves as the group's external advisor.

Other reports on the human genome project are in the offing. The National Academy of Sciences Board on Basic Biology plans to complete an evaluation of the project by June. For Congress, the Office of Technology Assessment is also evaluating the genome project. A draft of that report may be available this summer, although it is not officially due until the end of the year. 